\title{
The evolutionary history of eukaryotes: how the ancestral proto-lineage conserved in hypoxic eukaryotes led to protist pathogenicity
}

\author{
Vladimir F. Niculescu \\ Correspondence: besnea@aol.com \\ CrossMark \\ $\leftarrow$ Click for updates
}

Kirschenweg 1, 86420 Diedorf, Germany.

\begin{abstract}
The aim and the background of this paper was to investigate how ancient primitive eukaryotes evolved to the successful parasites they are today. In preparing this work, the most significant literature of the last years has been studied. We expand it by the results of our own research.

Results and conclusion: Anaerobic single-celled eukaryotes, such as Entamoeba invadens and Giardia lamblia, became successful invasive pathogens by using mechanisms inherited from the common ancestor (LECA). As described in previous papers pathogen protists have a surprising stem cell network (ancient protolineage) controlled by intrinsic and extrinsic mechanisms of cell conversion and differentiation inherited from the ancestor. Mechanisms leading to pathogenicity were not acquired after the organisms became parasitic, they were present before the single-celled organisms switched to parasitism. Only organisms possessing an extended ancestral stem cell system capable of switching between most oxidative (MO) and most hypoxic (MH) niches by changing metabolic pathways and antigenicity could develop into successful invasive pathogens like Entamoeba or Giardia. Related organisms not conserving all ancestral features evolved to become luminal commensals or free-living protists.
\end{abstract}

Keywords: Entamoeba invadens, stem cells, LECA, anaerobic metabolism, hypoxic and oxidative niches, commensalisms, parasitism

\section{Introduction}

Until recently, the evolutionary origin of stemness was largely unknown [1]. The central question has remained the same: did stem cells originate as single-celled organisms or not? [2]. It was Ernst Haeckel, 145 years ago, who first considered singlecelled organisms as the phylogenetic ancestors of multi-celled organisms [3]. However, until recently protist researchers could not develop adequate model systems to elucidate the evolutionary stem cell history and the correlations between life cycle and the multi-cellularity of single-celled organisms went unrecognized.

A few years ago the earliest stem cell lineages were considered those that occurred in basal Metazoans such as Spongia and Cnidaria (Hydra). The lack of available data for protists led developmental biologists to hypothesize that multi-cellularity originates from a number of multifunctional cell types existing only in metazoan ancestors $[4,5]$. As a result, some authors considered populations of protists to be homogenous communities, where each individual was self-sustaining and all cells are identical [6]. Thus, the appearance of stem cells was considered as a significant developmental event that happened exclusively in basal metazoans.

The discovery of self-renewing stem cell lines in protist pathogens such as E. invadens [7-11] re-opens the discussion on the evolutionary origin of stemness (Niculescu, Researchgate Feb. 17, 2014) and helps us better understand mechanisms leading to the parasitic way of life. Only a few years ago our knowledge of multicellularity in protist pathogens such as Entamoeba and Giardia was still rudimentary. Switching from vegetative forms (trophozoites) to a dormant/resistant form (cyst) and vice versa was considered the only differentiation events occurring in protists. "Spontaneous" encystment observed in cultures rich of nutrients remained unexplained, as was why an organism such as Entamoeba has two kinds of trophozoites (magna and minuta). Similarly, VSP switching in Giardia was considered more a mutational antigenic advantage rather than 
Vladimir F. Niculescu, Microbiology Discovery 2014,

a feature of differentiation.

In recent years, progress has been made in deciphering the stem cell biology of Entamoeba. Some years ago [8,9] we observed two different intra-specific self renewing stem cell lines (SRL) in [9] amoebic long term cultures (LT) grown in sediments with oxygen consuming bacteria (OCB niche). One is a more oxidative TD6 ${ }^{\mathrm{LT}}$ line that resides in most oxidative MO niches and the other is a more hypoxic line QD24 ${ }^{\mathrm{LT}}$ line residing in most hypoxic MH niches. In LT cultures TD6 ${ }^{\mathrm{LT}}$ proliferate only in the early growth phase as a non-continuous stem cell line, while QD24 is is a continuous cell line, proliferating indefinitely in cultures and subcultures.

\section{Materials and methods}

Materials and methods were described in a previous paper [9]. Amoebae were cultured in hypoxic sediments with 5-10 mg metabolically repressed bacteria (OCB associates) and strong hypoxic sediments with $15 \mathrm{mg} O C B$. For terminal differentiation $T$ stem cells were induced in strong hypoxic OCB sediments and hypoosmotic nutrient-free medium (AaEM).

\section{Results}

Hypoxia is the controlling factor for stemness and lineage development in E. invadens. It controls asymmetric and symmetric cell fate, cell line conversion and cell cycle length [8]. More oxic and light hypoxic conditions promote $E$. invadens stem cells to fast cycling while high and strict hypoxia leads stem cells to slow cycling respectively symmetric proliferation and cell cycle arrest in G2/M. In the $\mathrm{Aa}(\mathrm{Sm})$ cul tures of $E$. invadens hypoxia can be adjusted by the varying amount of OCB. The biochemical oxygen demand (BOD) of the microorganisms determines the $\mathrm{pO}_{2}$ value in the niche. Amoebic phagocytosis reduces the number of $O C B$ and indirectly controls hypoxia dynamics. The OCB sediments mimic in cultures the different stem cell niches for E. invadens present in the host.

In the present paper we hypothetized that the $\mathrm{MH} / \mathrm{MO}$ stem cell lineage of $E$. invadens (Table 1) conserved an early eukaryotic stem cell protolineage developed by LECA and present our results, sustaining this hypothesis.

\section{The primary stem cell lines p-SRL}

Searching in primary cultures for lineage development and cell line hierarchy [8] we recently found the primary self renewing stem cell line ( $p-S R L)$ generated by the eight metacystic amoebulae (A2 cells) resulting from the totipotent innercyst cell. A2 amoebulae convert by intrinsic mechanisms (A/P conversion) into cycling primary stem cells (CSP) that form the $\mathrm{p}$-SRL line. The primary stem cell line produced by asymmetrical division new cycling stem cells (CSP) and mitotic arrested sister cells (MAP) that are in fact reserve stem cells (RSC). Depending on passage conditions, oxidative stress and hypoxia in the new OCB niche, $\mathrm{P}$ cells convert in subcultures either to a secondary s-SRL stem cell line by $\mathrm{P} / \mathrm{S}$ conversion (more oxidative conversion) or, to a tertiary t-SRL stem cell line by a more hypoxic
$\mathrm{P} / \mathrm{T}$ conversion.

The subsidiary stem cell lines s-SRL and t-SRL

The secondary s-SRL line is a MO stem cell line that proliferates only in low hypoxic niches. In vitro it grows only in the more oxidative growth phase of the culture (t0-t28/t30) and proliferates in 5- 6 hrs by AGT5-6. In contrast to the s-SRL, the tertiary $\mathrm{t}-\mathrm{SRL}$ line is a ubiquitous stem cell line proliferating in culture in all oxidative and hypoxic conditions ( $\mathrm{t} 0 \mathrm{t} 128$ ). The t-SRL line cycled by AGT6 (fast cycling), AGT11-12 and AGT24 (slow cycling). Oxidative stress changed and CST proliferation from fast cycling to slow cycling and vice versa. The t-SRL is the only continuous stem cell line of $E$. invadens growing indefinitely in culture and hosts.

\section{Terminal differentiation (encystment)}

Mitotically arrested T cells (MAT) are reversible differentiated cells capable of cell cycle re-entry and cell line replenishing. When induced, they are capable of terminal differentiation, producing ITD cysts, while mitotically arrested $\mathrm{S}$ cells (MAS, precysts) encyst by autonomous terminal differentiationwithout any other inducement-giving rise to ATD cysts by cyclic encystment in culture (CE). The ATD cysts were known previously as "spontaneously" occurring cysts.

\section{Strict hypoxia and symmetric cell fate}

In strict hypoxic niches, (Table 2) the cycling T cells (CST) switch to symmetric cell fate giving rise to with switched all cells to asymmetric cell fate cells. Both daughter cells proliferate by extreme slow cycling ( $A G T \geq 48$ ). A slight oxygen increase during symmetric cell proliferation stopped cells at a G2/M checkpoint for cell fate (bifurcation point). At this checkpoint cells stop proliferation and wait for further decisions. When hypoxia increases again, cells continue strict hypoxic proliferation by symmetric division. Increasing $\mathrm{pO}_{2}$ values and hypoxia decrease switched all cells to asymmetric cell fate and asymmetric division.

\section{Disscussion}

The ancient hypoxic-oxidative protolineage of $E$. invadens is a bridge between the ancestral stem cell system developed by the last eukaryotic common ancestor LECA and the highly evolved stem cell systems of metazoans, mammalians and humans. It has conserved intrinsic and extrinsic mechanisms of cell differentiation, inherited from the ancestor. The discovery of stem cell lines and stem cell lineages in a single-celled organism like E. invadens is surprising and showed that asymmetric cell fate and stemness appeared much earlier in the evolutionary history of eukaryotes than anyone has imagined. It is reasonable to assume that the last common eukaryotic ancestor (LECA) was therefore a more complex ancestor than previously thought. Mechanisms of cell differentiation similar to those of $E$. invadens were probably conserved in many protists that likely have hidden stem cell lineages in their life cycle. 
Vladimir F. Niculescu, Microbiology Discovery 2014,

http://www.hoajonline.com/journals/pdf/2052-6180-2-4.pdf

doi: $10.7243 / 2052-6180-2-4$

Table 1. The stem cell system of $E$. invadens.

\begin{tabular}{lllllll}
\hline Cell type & Cell line & Conversion capacity & $\begin{array}{l}\text { Cycling stem cells } \\
\text { (D1) }\end{array}$ & $\begin{array}{l}\text { Cell cycle duration } \\
\text { (AGT in hrs) }\end{array}$ & $\begin{array}{l}\text { Mitotic arrested cells } \\
\text { (D2) }\end{array}$ & $\begin{array}{l}\text { Terminal differentiated } \\
\text { cells }\end{array}$ \\
\hline $\mathrm{P}$ & $\mathrm{p}-\mathrm{SRL}$ & $\mathrm{P} / \mathrm{S}, \mathrm{PT}$ & $\mathrm{CSP}$ & $\mathrm{AGT} / 6-24$ & MAP (RSC) & -- \\
$\mathrm{T}$ & $\mathrm{t}-\mathrm{SRL}$ & & CST & AGT/6-24 & MAT & ITD cysts \\
$\mathrm{S}$ & $\mathrm{s}-\mathrm{SRL}$ & $\mathrm{S} / \mathrm{T}$ & $\mathrm{CSS}$ & AGT5-6 & MAS (precyst) & ATD cysts (CE cysts) \\
\hline
\end{tabular}

Primary, secondary and tertiary stem cells (P, S, T); D1, D2, asymmetric daughter cells; D1 cells: self-renewing, cyclic stem cells (CSP, CSS, CST); p-SRL, s-SRL, t-SRL, self renewing stem cell lines; D2 cells: mitotic arrested, reversible differentiated daughter stem cells, as reserve stem cells (MAP and MAT, as RSC); ATD cysts, autonomous differentiated cysts; CE, cyclic encystment; ITD, hypoxic induced cysts; AGT, average generation time.

Table 2. The ancient stem cell protolineage of the hypoxic eukaryote E. invadens.

\begin{tabular}{|c|c|c|c|c|c|}
\hline $\begin{array}{l}\mathrm{pO}_{2} \text { value of the } \\
\text { niche }(\text { in } \%)^{*}\end{array}$ & Hypoxic/oxidative range & $\begin{array}{l}\text { Asymmetric/symmetric cell } \\
\text { fate (A/S) }\end{array}$ & Stem cell lines (protolineage) & $\begin{array}{l}\text { AGT } \\
\text { (in hrs) }\end{array}$ & Proliferation \\
\hline $0.1-1.0$ & strict hypoxic (SH) & $S$ & identical cells & $\mathrm{AGT} \geq 48$ & $\mathrm{G} 2 / \mathrm{M}$ arrest \\
\hline $1.0-2.0$ & high hypoxic $(\mathrm{HH})$ & A & $\mathrm{t}-\mathrm{SRL}$ & AGT24 & slow cycling \\
\hline \multirow[t]{2}{*}{$2.0-5.0$} & \multirow{2}{*}{$\begin{array}{l}\text { moderate hypoxic/ } \\
\text { mild hypoxic (MH) }\end{array}$} & A & $\mathrm{t}-\mathrm{SRL}$ & AGT11-12 & -- \\
\hline & & -- & p-SRL & AGT $<15$ & -- \\
\hline$>5.0(\leq 8.1 \mathrm{mg} / \mathrm{l})^{* *}$ & $\begin{array}{l}\text { low hypoxic (LH); light oxidative } \\
\text { (LO) }\end{array}$ & A & s-SRL & AGT6 & fast cycling \\
\hline
\end{tabular}

${ }^{\star} \mathrm{pO}_{2}$ values according to Carreau et al., 2011; ${ }^{* *}$ oxygen concentration (dissolved oxygen) in $26^{\circ} \mathrm{C}$ warm water (http://water.epa.gov/ type/rsl/monitoring/vms52.cfm).

Encystment occurs as the terminal differentiation step in prominent commensals and pathogens such as Entamoeba, Naegleria, Acanthamoeba, lodamoeba, Giardia, Leishmania and Balantidium and also in free living exotics as Blephyrisma, Pleurotrichia, Uroleptus, Didinium, Opistonecta and Colpoda [12]. Some of them encyst "spontaneously" that means autonomous independent of whether nutritive reserves are abundant or not. Colpoda even produces two different types of cysts. One is the reproductive, independent cyst, produced under favorable conditions forming by successive divisions two, four or eight daughter cells. The second type is a protective cyst formed when food is lacking [13]. Asymmetric division and differentiation events occurring in the facultative pathogen ciliate Colpoda cucullus show convergence with the mechanisms of cell differentiation observed in the pathogen protist $E$. invadens [14]. Colpoda's two types of reproductive and protective cysts are further evidence that mechanisms of autonomous terminal differentiation (ATD) are ancestral and conserved in free-living and facultative pathogens also.

\section{LECA and the hypoxic-oxidative protolineage}

The above data suggest that the basic mechanisms for stem cell differentiation were evolved by LECA. According to Morrison et al., [15], there are basic common properties of stem cells which extend across many species and common molecular mechanisms shared by all stem cells. About 2000 MY ago during the early Paleoproterozoic age, the oxygenation began with cyanobacteria, that produced oxygen by anaerobic photosynthesis. By the end of Paleoproterozoic age LECA completes its basal development (1750-1600 MYA) [16] $\mathrm{O}_{2}$ produced by cyanobacteria was absorbed in oceans and seabed rocks to iron-oxides. During the Meso-and Neo-proterozoic ages $\mathrm{O}_{2}$ is released from the oceans but it absorbed by land surfaces. The free gas accumulation in the atmosphere began towards the end of proterozoic, as $\mathrm{O}_{2}$ sinks filled (850 MYA, see "The great oxygenation event", Wikipedia). With the beginning of the late Neoproterozoic diversification, photosynthesis occurred oxygenically with a variety of eukaryotes producing oxygen as a major by product. Although eukaryotic branching began early in Proterozoic age, the explosion in the number and distribution of abundant marine eukaryotes began about 800 MYA [17]. Researchers believe that most of the organic matter (photosynthetic organisms, cyanobacteria relatives, algae and marine eukaryotes) remained suspended in the upper oxygenated ocean providing the mid-neoproterozoic plankton and the marine ecosystem. The organic material was exported into anoxic sub-surface layers and finally remineralized via anaerobic fermentation by sulfateand iron reducing bacteria in the depth. Organic matter and $\mathrm{O}_{2}$ export lead to partially oxygenated sub-surface waters and new ecological niches.

It may be, that in stratified nutrient-rich water columns moving between anoxic to progressively oxygenated niches rich in nutrients, LECA adopted an adaptative strategy using $\mathrm{O}_{2}$ to optimize its metabolic pathways. The molecular machinery present in LECA at the time of the great Cambrian explosion 
Vladimir F. Niculescu, Microbiology Discovery 2014,

http://www.hoajonline.com/journals/pdf/2052-6180-2-4.pdf

doi: 10.7243/2052-6180-2-4

is however largely unknown [18], but our experience with E. invadens $[\mathbf{8 , 9}$ leads to the assumption that by switching back and forth between high, middle and low hypoxic subsurface layers rich on nutrients, LECA needed alternative mechanisms for utilizing available resources and thus ensuring its survival. It converts between symmetric and asymmetric cell fate and differentiated cell lines for accelerated cell cycle, and autonomous encystment. At the end of this evolutionary period, LECA developed the first hypoxicoxidative protolineage linking together the more oxidative neo-proterozoic mechanisms for stemness, asymmetric cell division and cell differentiation with the paleo-proliferation patterns of the symmetric cell division, identical daughter cells and slow cycling. It improved proliferation to fast cycling using the oxygen as a catalyst for its anaerobe metabolism.

Thus, at the begining of the Cambrian LECA was a "complete" eukaryote [19] possessing a modern nucleus and associated features such nuclear pore complexes, linear chromosomes and centromeres, nucleolus, endoplasmic reticulum, Golgi apparatus, mitochondria of alpha-proteobacteria origin and flagella, a complex cytoskeletal network based on actin and microtubulin, a complete endocytosis vesicle system, a modern cell cycle [20], stemness and sexuality: it underwent mitosis and meiosis. All hypotheses from the origin of eukaryotes believe that early eukaryotic lineages contributed to the modern eukaryotic genome either by vertical endosymbiotic gene transfer (EGT) or by diverse forms of horizontal gene transfer (HGT, LGT). Researchers agreed that the eukaryotic genome is a mosaic of archaea-related, bacteria-related and eukaryotic-specific genes. Genes from bacteria were transferred in the eukaryotic stem branch by EGT and HGT $[20,34]$.

Fossils of the late Mesoproterozoic and early Neoproterozoic showed that most of the cytological and molecular complexities of eukaryotes evolved very early in the Proterozoic, but environmental conditions delayed their diversification within clades until oxygen and predation pressure increased significantly [21]. Javaux [21] makes a very complex presentation based on mesoproterozoic eukaryote fossils. She differentiates between early low-level characteristics and the high-level characteristics of the extant phagotropic heterotrophs and facultative aerobes at the time of the eukaryotic explosion. 1500-1300 MYA early mesoproterozoic fossils showed marked cytological, genetical and ecological complexities and attest to the evolution of multicellularity and cell differentiation in relation to environmental heterogeneity. LECA follows the vertical diversification of marine ecological niches (water column gradients), rather then simply horizontal distribution.

Paleoproterozoic and mesoproterozoic eukaryotes dividing by binary fission, had vegetative and resting stages (cysts) with more or less sophisticated excystment structures. First cyst structures were found 1800 MYA and were considered as a response to starvation. LECA molecular machinery evolved im Meso- and Neo-proterozoic from simple proliferation and differentiation mechanisms (binary fission, induced encystment) to more complex molecular mechanisms for asymmetric cell fate, multicellularity, stemness and vegetative differentiation. This evolution followed the progressive oxygenation and nutrient enrichment of ocean sub-surface layers. The new ecological niches from the mid-neoproterozoic lead LECA to stem cells, autonomous encystment and organized protolineages.

\section{Commensalism and parasitism}

Between branching and developing or adapting to the parasitic way of life bacterivorous Amoebozoa such as Entamoeba and heterotrophic Excavata such as Giardia occupied niches as commensals in association with oxygen consuming bacteria (OCB niches) [8,9]. While existing as commensals, representatives of Amoebozoa and Excavata underwent str-uctural and genomic developmental loss, reducing their no longer needed mitochondria to mitosomes [22]. In contrast to Lwoff's popular doctrine of regressive evolution, that states mitochondria and flagella loss, are a consequence of parasitism [23], it is today clear that the reductive development occurred much earlier in the evolutionary history, before the commensals switched to parasites [24]. Thus, more than 1000 free-living protists are amitochondriate [25], without passing through parasitic conversion.

The transition from the commensal to the parasitic way of life, succeeded only in luminal protists that could overexpress exoenzymes. Only protists with complex stem cell lineages and differentiation mechanisms as E. invadens and E. histolytica become pathogens, while commensals as E. coli, E. dispar and E.moshkowskii remain apathogenic. There are good reasons to expect that the pathogenic stem cell line is the t-SRL, a cell line living indefinitely in a wide scale of oxic and hypoxic niches. It is most capable of tissue invasion and pathogenicity. In contrast, the most oxic s-SRL stem cell line that encysts autonomously, is the non-continuous apathogenic stem cell line of E. invadens.

Cytopathic effectors causing host cell damage were reported by Mirelman [26]. Comparing cystein proteinase enzymes from non-pathogenic (E. dispar, E. coli) and pathogenic strains (E. histolytica, E. invadens) Seghal [27] concluded as early as 1996 "that pathogenesis is determined more by quantitative levels of key molecules than by total absence of these in non-pathogenic species". In recent years new insights into tissue invasion mechanisms identified genes differentially- expressed in virulent and avirulent phenotypes [28-30]. Regulatory mec-hanisms for enzyme over-expression and down regulation are expected to occur in stem cell line differentiation.

\section{Harboring in hypoxic and oxidative niches}

Similar to their branching relatives, amitochondrial pathogens such as Entamoeba and Giardia are hypoxic eukaryotes capable of leaving and surviving in a wide scale of environments of different $\mathrm{pO}_{2}$ levels, from strict hypoxic to light oxidative. The alternativ terms "anaerobe" or "micro-aerophile" are less suitable. 
These terms suggest leaving in anoxic niches (anaerobe) or in environments of moderate oxygen content (micro-aerophile). "Hypoxic" means a wide spread of $\mathrm{pO}_{2}$ ranges below $5 \%$. Entamoeba live and proliferates in luminal microenvironments and tissue niches varying their oxygen content $\left(\mathrm{pO}_{2}\right.$ between $<1 \%$ and $\geq 5 \%$ ). $\mathrm{pO}_{2}$ is a key indicator of the physiological state of the host tissues, resulting from the balance between oxygen delivery and oxygen consumption. E. histolytica moves from luminal compartments and $O C B$ niches into more oxidative intestinal tissues $\left(4.4 \% \text { to } 7.6 \% \pm 0.3 \% \mathrm{O}_{2}\right)^{*}$ and via blood transfer $\left(5.3 \%\right.$ to $\left.13.2 \% \mathrm{O}_{2}\right) *$ into liver $\left(5.4 \% \pm 0.7 \% \mathrm{O}_{2}\right)^{*}$ and muscle $\left(3.8 \% \pm 0.2 \% \mathrm{O}_{2}\right) *$ [31]. Similarly, E. invadens invades in reptilia any part of the bowel and tissues, passages portal vessels and embolizes to liver (abcesses and tissue necrosis) and also in lung, heart, kidneys, brain and muscles, where tissue physioxia declines by oxygen deprivation, as a consequence of inflammation and pathogenic events.

\section{*mean values of $\mathrm{pO}_{2}$}

According to Carreau et al., 2011 [32] the terms currently used to distinguish between the tissue oxygenation levels were "physiological normoxia" or "organ physioxia", meaning 3\% to $10 \% \mathrm{pO}_{2}$ levels. Hypoxia spans the lower $\mathrm{pO}_{2}$ ranges $(1 \%-$ $5 \% \mathrm{pO}_{2}$ ). Any researcher [31] can differentiate between mild and moderate hypoxia (2\%-5\%) and strict hypoxic condition $(\leq 1 \%)$. Mammalian cells in cultures were commonly grown at higher oxygenation than organ physioxia (11\%-19.5\% $\mathrm{pO}_{2}$ ). After exposure to hypoxia mammalian cells respond by producing hypoxia-inducible factors (HIF-a and HIF-1a) that control cell production and cellular glucose uptake [33]. In mammalian stem cells hypoxia is considered as favoring the stem cell state, as seen in multiple stem cell lineages residing in strict hypoxic niches at notorious $\mathrm{pO}_{2}$ values between $0.1 \%$ and $1.0 \%$. A characteristic of strong hypoxic niches $\left(\mathrm{pO}_{2} \leq 1 \%\right)$ is that stem cell proliferation decreases to slow-cycling or cell cycle arrest, due to regulation by HIFs. Higher oxygen tensions $\left(2 \%\right.$ to $\left.5 \% \mathrm{O}_{2}\right)$ do not affect the proliferation of human embryonic stem cells (ESC).

\section{Conclusions}

Undoubtedly, the pathogenetic success of Entamoebae originates mainly from the widely conserved oxidativehypoxic protolineage and the multliple cell types specialized for an effective invasive infection that ends in the case of $E$. invadens by host death. Despite the limited life span of the non-continuous primary $p$-SRL, mitotic arrested $P$ cells (MAP) survive for longer periods of time even in oxydative niches repressing cell cycle re-entry. When permissive environmental conditions are encountered, MAP cells restore secondary and tertiary stem cell lines that start new invasive waves. The most oxic s-SRL remains luminal and give rise to ATD cysts, as long as this non-continuous stem cell line proliferates and survives. Increased hypoxia converts $S$ cells (CSS) into a continuous tertiary stem cell line t-SRL capable of tissue invasion in all oxygenic and less oxygenic tissues. CST cells produce permanently mitotic arrested MAT cells capable of phagocytosis. MAT cells are capable of re-entering the cell cycle until the host is killed. In hypoxic non-nutritive conditions MAT cells encyst to ITD cysts. In strong hypoxic niches CST cells switch to fast cycling and symmetric division giving rise to identical daughter cells.

The ancient oxidative-hypoxic protolineage inherited from LECA assures a successful parasitic life style in $E$. invadens, in that the continuous t-SRL stem cell line ensures invasiveness and pathogenicity and the non-continuous most oxic s-SRL cell line ensures rapid cyst formation. Mechanisms of hypoxic induced cell conversion and autonomous cell differentiation in nutrient-rich environments are inherited from the common ancestor (LECA). Parts of the oxidative-hypoxic protolineage and their mechanisms for asymmetric cell fate seemed to be conserved in other free-living and opportunistic pathogenic protists such as Colpoda [14] and others.

\section{Competing interests}

The author declares that he has no competing interests.

\section{Acknowledgement}

The author expresses his gratitude to Dr. Dennis Thomas (english speaker) for reading the manuscript and excellent support.

\section{Publication history}

EIC: Todd R. Callaway, Food and Feed Safety Research Unit, USA. Received: 15-May-2014 Final Revised: 28-Jul-2014

Accepted: 18-Aug-2014 Published: 05-Sep-2014

\section{References}

1. Hemmrich G, Khalturin K, Boehm AM, Puchert M, Anton-Erxleben F, Wittlieb J, Klostermeier UC, Rosenstiel P, Oberg HH, Domazet-Loso T, Sugimoto T, Niwa $\mathrm{H}$ and Bosch TC. Molecular signatures of the three stem cell lineages in hydra and the emergence of stem cell function at the base of multicellularity. Mol Biol Evol. 2012; 29:3267-80. | Article | PubMed

2. Chakraborty $\mathrm{C}$ and Agoramoorthy $\mathrm{G}$. Stem cells in the light of evolution. Indian J Med Res. 2012; 135:813-9. | Article | PubMed Abstract | PubMed Full Text

3. Maehle AH. Ambiguous cells: the emergence of the stem cell concept in the nineteenth and twentieth centuries. Notes Rec R Soc Lond. 2011; 65:359-78. | Article | PubMed Abstract | PubMed Full Text

4. Arendt $D$. The evolution of cell types in animals: emerging principles from molecular studies. Nat Rev Genet. 2008; 9:868-82. | Article | PubMed

5. Arendt $D$, Hausen $H$ and Purschke G. The 'division of labour' model of eye evolution. Philos Trans R Soc Lond B Biol Sci. 2009; 364:2809-17. | Article I PubMed Abstract | PubMed Full Text

6. Funayama N. Stem cell system of sponge. In: Stem Cells from Hydra to Man. (ed.T.C.G. Bosch), Springer, Berlin, Heidelberg. 2008; 17-35. | Book

7. Niculescu VF. The primitive cell system of Entamoeba invadens. ICOPA III, Third Intern. Congress of Parasitology, section A11, München 1974. | $\underline{\text { Pdf }}$

8. Niculescu VF. The stem cell biology of the hypoxic pathogen Entamoeba invadens in the context of eukaryotic cell evolution. 2014.

9. Niculescu VF. Growth of Entamoeba invadens in sediments with metabolically repressed bacteria leads to multicellularity and redefinition of the amoebic cell system. Roum Arch Microbiol Immunol. 2013; 72:25-48. I PubMed 
Vladimir F. Niculescu, Microbiology Discovery 2014,

http://www.hoajonline.com/journals/pdf/2052-6180-2-4.pdf

10. Niculescu VF. On the origin of stemness and ancient cell lineages in single-celled eukaryotes. SOJ Microbiol Infect Dis. 2014; 2:1-3. I Article

11. Niculescu VF. The cell system of Giardia lamblia in the light of protist stem cell biology. Stem Cell Biology and Research. 2014; 1:3. | Article

12. Rosenberg LE. Cysts stages in Opisthonecta henneguyi. Trans Am Microscope. 1938; 57:147. I Article

13. Stout JD. Protozoa and the soil. Tuatara. 1952; 4:103-107. | Article

14. Niculescu VF. Evidence for asymmetric cell fate and hypoxia induced differentiation in the facultative pathogen protist Colpoda cucullus. 2014. | Article

15. Morrison SJ, Shah NM and Anderson DJ. Regulatory mechanisms in stem cell biology. Cell. 1997; 88:287-98. | Article | PubMed

16. Parfrey LW, Lahr DJ, Knoll AH and Katz LA. Estimating the timing of early eukaryotic diversification with multigene molecular clocks. Proc Natl Acad Sci U S A. 2011; 108:13624-9. | Article | PubMed Abstract | PubMed Full Text

17. Tziperman E, Halevy I, Johnston DT, Knoll AH and Schrag DP. Biologically induced initiation of Neoproterozoic snowball-Earth events. Proc Natl Acad Sci U S A. 2011; 108:15091-6. | Article | PubMed Abstract | PubMed Full Text

18. Koumandou VL, Wickstead B, Ginger ML, van der Giezen M, Dacks JB and Field MC. Molecular paleontology and complexity in the last eukaryotic common ancestor. Crit Rev Biochem Mol Biol. 2013; 48:373-96. | PubMed Abstract | PubMed Full Text

19. Vesteg $M$ and Krajcovic J. Origin of eukaryotic cells as a symbiosis of parasitic alpha-proteobacteria in the periplasm of two-membranebounded sexual pre-karyotes. Commun Integr Biol. 2008; 1:104-13. | PubMed Abstract | PubMed Full Text

20. Rochette NC, Brochier-Armanet C and Gouy M. Phylogenomic test of the hypotheses for the evolutionary origin of eukaryotes. Mol Biol Evol. 2014; 31:832-45. | Article | PubMed Abstract | PubMed Full Text

21. Javaux EJ. The early eukaryotic fossil record. In "Eukaryotic membranes and cytoskeleton: origins and evolution", ed. Gaspar Jakely. Landes Bioscience and Springer Sci Bussines Med. 2007.

22. Muller M, Mentel M, van Hellemond JJ, Henze K, Woehle C, Gould SB, Yu RY, van der Giezen M, Tielens AG and Martin WF. Biochemistry and evolution of anaerobic energy metabolism in eukaryotes. Microbiol Mol Biol Rev. 2012; 76:444-95. | Article | PubMed Abstract | PubMed Full $\underline{\text { Text }}$

23. Lwoff A. L'evolution physiologique. Etude de pertes de fonctions chez les microorganisms. Paris, Hermann et Cie. 1943.

24. Bapteste E, Brinkmann H, Lee JA, Moore DV, Sensen CW, Gordon P, Durufle L, Gaasterland T, Lopez P, Muller M and Philippe H. The analysis of $\mathbf{1 0 0}$ genes supports the grouping of three highly divergent amoebae: Dictyostelium, Entamoeba, and Mastigamoeba. Proc Natl Acad Sci U S A. 2002; 99:1414-9. | Article | PubMed Abstract | PubMed Full Text

25. Lane N. Energetics and genetics across the prokaryote-eukaryote divide. Biol Direct. 2011; 6:35. | Article | PubMed Abstract | PubMed Full Text

26. Mirelman D, Anbar M and Bracha R. Trophozoites of Entamoeba histolytica epigenetically silenced in several genes are virulenceattenuated. Parasite. 2008; 15:266-74. I PubMed

27. Seghal D, Bhattacharya A and Bhattacharya S. Pathogenesis of infection by Entamoeba histolytica. J Biosci. 1996; 21:423-432. | Article

28. Bansal D, Ave P, Kerneis S, Frileux P, Boche O, Baglin AC, Dubost G, Leguern AS, Prevost MC, Bracha R, Mirelman D, Guillen N and Labruyere E. An ex-vivo human intestinal model to study Entamoeba histolytica pathogenesis. PLoS Negl Trop Dis. 2009; 3:e551. I Article I PubMed Abstract | PubMed Full Text

29. Singh $U$ and Ehrenkaufer GM. Recent insights into Entamoeba development: identification of transcriptional networks associated with stage conversion. Int J Parasitol. 2009; 39:41-7. | Article | PubMed Abstract | PubMed Full Text

30. Wilson IW, Weedall GD and Hall N. Host-Parasite interactions in Entamoeba histolytica and Entamoeba dispar: what have we learned from their genomes? Parasite Immunol. 2012; 34:90-9. | Article | PubMed Abstract | PubMed Full Text
31. Mohyeldin A, Garzon-Muvdi T and Quinones-Hinojosa A. Oxygen in stem cell biology: a critical component of the stem cell niche. Cell Stem Cell. 2010; 7:150-61. | Article | PubMed

32. Carreau A, El Hafny-Rahbi B, Matejuk A, Grillon C and Kieda C. Why is the partial oxygen pressure of human tissues a crucial parameter? Small molecules and hypoxia. J Cell Mol Med. 2011; 15:1239-53. | Article | PubMed

33. Wiesener MS, Jurgensen JS, Rosenberger C, Scholze CK, Horstrup JH, Warnecke C, Mandriota S, Bechmann I, Frei UA, Pugh CW, Ratcliffe PJ, Bachmann S, Maxwell PH and Eckardt KU. Widespread hypoxia-inducible expression of HIF-2alpha in distinct cell populations of different organs. FASEB J. 2003; 17:271-3. | Article | PubMed

34. Takishita K, Chikaraishi Y, Leger MM, Kim E, Yabuki A, Ohkouchi N and Roger AJ. Lateral transfer of tetrahymanol-synthesizing genes has allowed multiple diverse eukaryote lineages to independently adapt to environments without oxygen. Biol Direct. 2012; 7:5. I Article | PubMed Abstract | PubMed Full Text

\section{Citation:}

Niculescu VF. The evolutionary history of eukaryotes: how the ancestral proto-lineage conserved in hypoxic eukaryotes led to protist pathogenicity. Microbiol Discov. 2014; 2:4. http://dx.doi.org/10.7243/2052-6180-2-4 